\title{
Synthesis of Methionine-Containing Chromium Chelatesand Study of its Biological Activity
}

\author{
G. Chagelishvili, A. Chkuaseli, I. Beshkenadze, M. Gogaladze, N. Klarjeishvili
}

\begin{abstract}
Synthesis conditions are established and methionine-containing chromium chelate compounds are synthesized: $\quad \mathrm{Cr}(\mathrm{Mt})(\mathrm{CH} 3 \mathrm{COO}) 2 \quad$ (I); Cr(Mt)2(CH3COO)•2H2O (II); $\quad \mathrm{Cr}(\mathrm{Mt}) 3 \bullet 2 \mathrm{H} 2 \mathrm{O} \quad$ (III). Composition of synthesized compounds by microelement analysis. Individuality by measuring the melting temperature. Chelates have been studied by a number of physico-chemical research methods. In particular, by the method of thermographic research. It is established that they decompose in steps at the temperature range 540-6300C in the following order: 1- water molecules are broken down; 2-oxidizing acetate ions; 3-Oxidized methionine molecule. The final products of decomposition are a mixture of chromium sulfide and oxide (I); Chromium sulfide (II) or a mixture of chromium sulfide and coal (III). Spectrophotometric research has established that methionine acts as a cyclic ligand, binding to chromium atoms by means of amino group nitrogen and carboxyl ion (COO-) oxygen atoms to form five-membered metalcycles.

An experiment on a broiler was conducted to study the biological activity of a chromium chelate compound. The dynamics of broiler live weight, absolute live weight gain, daily weight gain, poultry maintenance, feed consumption per $1 \mathrm{~kg}$. body weight, broiler growth efficiency are studied. It has been established that the use of chromium chromate in broiler feed had a positive effect on all of the above parameters and the optimal dose of chromium chelate is $100 \mathrm{mkg}$. per wing.
\end{abstract}

Index Terms - Chrome; Chelate;Broiler;Feed consumption; Weight gain.

\section{INTRODUCTION}

Providing the population with cheap, high-quality and ecologically safe agricultural products is very important today. One of the main reasons for the low quantity and quality of these products is the lack of micronutrients.

Therefore, the most important condition for solving the problem is to provide them with a defined composition, quantity and optimal ratio of micronutrients, which is achieved by creating and using premixes containing artificial micronutrients. This fact is explained by the fact that the

G. Chagelishvili, Agrarian University, Kakha Bendukidze University Campus. 240 David Aghmashenebeli Alley,

0131. Tbilisi, Georgia

A. Chkuaseli, Agrarian University, Kakha Bendukidze University Campus. 240 David Aghmashenebeli Alley,

0131. Tbilisi, Georgia

I. Beshkenadze, Petre Melikishvili Institute of Physical and Organic Chemistry Ivane Javakhishvili Tbilisi ,State University, 31 A. Politkovskaya. 0186, Tbilisi, Georgia

M. Gogaladze, Petre Melikishvili Institute of Physical and Organic Chemistry Ivane Javakhishvili Tbilisi ,State University, 31 A. Politkovskaya 0186, Tbilisi, Georgia

N. Klarjeishvili, Petre Melikishvili Institute of Physical and Organic Chemistry Ivane Javakhishvili Tbilisi ,State University, 31 A. Politkovskaya. 0186, Tbilisi, Georgia function of micronutrients in a living organism is multifaceted, namely:

$\checkmark$ Participate in the construction of supporting

tissues

$\checkmark$ Ensure the maintenance of homeostasis of

the internal environment

$\checkmark$ Provide cell membrane maintenance

$\checkmark$ Provide activation of biochemical reactions

by acting on the enzyme system

$\checkmark$ Directly or indirectly affects the function of the endocrine glands

$\checkmark$ Act on the microflora of the symbiotic gastrointestinal tract. Micronutrients are included in the composition of the cell's genetic machinery and biologically active compounds. The strong influence of micronutrients on physiological processes is explained by the fact that they are part of enzymes, coenzymes, participate in the regulation of vital processes.

As micronutrients perform their functions in biosystems in the form of chelate compounds, there is a sharp increase in their biological activity when introduced in this form. This fact is confirmed by the results of the research of scientists working in this field [1-9] and the experiment we have conducted over the years [10-15].

According to the detailed norms of nutrition, currently premixes include micronutrients $\mathrm{Mn}, \mathrm{Zn}, \mathrm{Fe}, \mathrm{Co}, \mathrm{Cu}, \mathrm{I}$ and Se. However, there is a very large number of vital (essential) micronutrients that can not be replaced by other micronutrients and in the absence or absence of which the body can not grow normally and end the life cycle. Among these micronutrients, our focus has been on chromium. Chromium is an important, demanding, essential trace element. Yet by detailed norms of animal nutrition, chromium is not included in the premixes; Consequently, its impact on poultry productivity, growth, development, etc. has not been established to date. $30-40 \%$ of birds that fall during the last period of broiler growth show signs of "sudden death" due to weakness of the cardiovascular system and poor functioning (heart attack). One of the contributing factors to this fact, we think, is chromium deficiency. Georgia is an endemic center of chromium deficiency. Therefore, the use of chert chromium in the composition of mixed poultry feed premixes, we think, will help reduce diseases caused by deficiency of these micronutrients. Therefore, the aim of our study was to synthesize methionine-containing chelate compounds, physico-chemical research and to determine its impact on bird growth and development, productivity and physiological condition. 
The aim of the study was to study and determine the role of the micronutrient for life, chromium in broiler productivity, its impact on growth intensity, food compensation, animal viability, meat quality and taste, some morphological and biochemical parameters of blood.

The aim of the study was to determine the optimal dose of chromium, a micronutrient necessary for life in broiler nutrition.

\section{COMPUTATIONAL METHOD}

$\checkmark$ Microelement analysis - Determination of melting temperature of methionine-containing chromium chelate compounds;

$\checkmark$ To determine the individuality of the cheeks;

$\checkmark$ Solubility - To study the qualitative solubility of chelate compounds in different solvents;

$\checkmark$ Conductometric study - determination of dissociation constant and dissociation quality of solutions containing solutions of chelate compounds;

$\checkmark \quad$ Thermographic analysis - to study the thermal stability of thermal compounds and the sequence of the thermolysis process;

$\checkmark$ Spectrophotometric study to determine the nature of the bond between a chromium ion and a methionine molecule;

$\checkmark$ Weighing method - to determine the weight of the broiler;

$\checkmark$ Food Consumption Recognition Method - for Food Conversion and Consumption of Nutrients (Protein, Energy).

\section{RESULTS AND ANALYSIS}

To obtain methionine-containing chromate compounds (Table 1), we have developed a sophisticated and simplified method: chromium acetate $\left(\mathrm{Cr}\left(\mathrm{CH}_{3} \mathrm{COO}\right)_{3}\right)$ and methionine (Mt) $1: 1$; Mixtures in molar ratios of $1: 2$ and $1: 3$ are dissolved in a minimum volume of water under heating and intense stirring conditions. A small amount of ammonia is added to each of them to a weakly alkaline area $(\mathrm{pH}=8)$. Filter and keep all three of them at room temperature. The compounds obtained after a few days are filtered, washed with water, ether and dried at room temperature. The melting point/SMP10/ melting temperature on the melting temperature meter determines the individuality of the synthesized chelates (Table 1); Qualitative solubility of compounds in different solvents is also defined, according to which they are characterized by good solubility in water and dimethylformamide, and relatively poor solubility in alcohol and acetone (Table 1).

Table 1

\begin{tabular}{|c|c|c|c|c|c|c|c|c|c|c|}
\hline \multicolumn{11}{|c|}{ Some physical characteristics of chromium chelate compounds } \\
\hline \multirow[b]{2}{*}{ \# } & \multirow[b]{2}{*}{$\begin{array}{l}\text { The formula of the } \\
\text { compound }\end{array}$} & \multirow[b]{2}{*}{$\begin{array}{c}\text { Molar } \\
\text { mass }\end{array}$} & \multirow{2}{*}{$\begin{array}{c}\text { Melting } \\
\mathbf{t}^{\mathbf{0}} \mathbf{c}\end{array}$} & \multicolumn{4}{|c|}{ Solubility } & \multicolumn{3}{|c|}{$\begin{array}{c}\text { Conductometric survey } \\
\text { results }\end{array}$} \\
\hline & & & & $\stackrel{\mathscr{z}}{\tilde{w}}$ & $\begin{array}{l}\bar{\Xi} \\
\bar{z} \\
\bar{z}\end{array}$ & 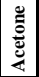 & 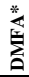 & $\alpha$ & $\mathbf{R}^{2}$ & $\mathbf{K}$ \\
\hline 1 & $\mathrm{Cr}(\mathrm{Mt})\left(\mathrm{CH}_{3} \mathrm{COO}\right)_{2}$ & 318.35 & $>300$ & + & $+\mathrm{t}$ & $+\mathbf{t}$ & + & 0.6531 & 0.9796 & 0.0269 \\
\hline 2 & $\mathrm{Cr}(\mathrm{Mt})_{2}\left(\mathrm{CH}_{3} \mathrm{COO}\right) \cdot 2 \mathrm{H}_{2} \mathrm{O}$ & 443.6 & 123 & + & $+\mathrm{t}$ & $+\mathbf{t}$ & + & 0.4873 & 0.9433 & 0.0797 \\
\hline 3 & $\mathrm{Cr}(\mathrm{Mt})_{3} \cdot 2 \mathrm{H}_{2} \mathrm{O}$ & 532.69 & 215 & + & $+\mathrm{t}$ & $+\mathbf{t}$ & + & 0,8446 & 0,9358 & 0,0067 \\
\hline
\end{tabular}

Table 1. Conductometric study of $\mathrm{pH}$ and Conductivity Sensor LE703 was performed to determine the degree of dissociation and dissociation constant of chromium chelate compounds. For compounds for this purpose: $\mathrm{Cr}$ $(\mathrm{Mt})\left(\mathrm{CH}_{3} \mathrm{COO}\right)_{2} ; \mathrm{Cr}(\mathrm{Mt})_{2}\left(\mathrm{CH}_{3} \mathrm{COO}\right) \cdot 2 \mathrm{H}_{2} \mathrm{O} ; \mathrm{Cr}(\mathrm{Mt})_{3} \cdot 2 \mathrm{H}_{2} \mathrm{O}$ solutions were prepared in the concentration range from $0.1 \mathrm{~N}$ to $0.0025 \mathrm{~N}$. The experiment was conducted in a thermostat at $25^{\circ} \mathrm{C}$. The results of the experiment are presented in Table 1. $\mathrm{R}^{2}$ - (Determination coefficient), called the approximation reliability coefficient, which shows how close the experimental data is to the corresponding function of the graph. As can be seen from the table it is quite high and ranges from 0.9358-0.9796. The degree of dissociation, which is a variable, increases with dilution. As for the values of the dissociation constant, it does not depend on the dilution of the solution, the constant value, as shown in the table for chelate $\mathrm{Cr}(\mathrm{Mt})_{3} \cdot 2 \mathrm{H}_{2} \mathrm{O}-\mathrm{K}$ (dissociation constant), is quite low equal to 0.0067 . For comparison, the dissociation constant of chromium acetate under the same conditions is determined and it is equal to $\mathrm{K}=0.12031$.

$\mathrm{Cr}(\mathrm{Mt})\left(\mathrm{CH}_{3} \mathrm{COO}\right)_{2}, \quad \mathrm{Cr}(\mathrm{Mt})_{2}\left(\mathrm{CH}_{3} \mathrm{COO}\right) \cdot 2 \mathrm{H}_{2} \mathrm{O} \quad$ and $\mathrm{Cr}(\mathrm{Mt})_{3} \cdot 2 \mathrm{H}_{2} \mathrm{O}$ of synthesized synthetic compounds were studied for thermal stability and sequence of thermolysis on the instrument ATA: NETZSCH. The compounds were studied under the following conditions: $T G=100 \mathrm{mg}$, $\mathrm{T}=7000 \mathrm{C}$, DTA=DTG=1/5 heating rate of samples at $5 \mathrm{~g} . /$ min. (Table 2).

As can be seen from the thermographic study, all thermograms are characterized by several endo and exo effects and corresponding effects on the curve (Table 2).

Analysis of II thermogravigrams of crude compound $\mathrm{Cr}(\mathrm{Mt})\left(\mathrm{CH}_{3} \mathrm{COO}\right)_{2}$ shows that the endoeffect I $\left(230^{\circ} \mathrm{C}\right)$ corresponds to an oxidation of $0.5 \mathrm{~mol} \mathrm{CH}_{3} \mathrm{COO}^{-}$(mass loss: practical $8.9 \%$, theoretical $9.26 \%$ ), then the endo effect $\left(270^{\circ} \mathrm{C}\right)$ exceeds $0.6 \mathrm{~mol}$ (mass loss: practical $12.4 \%$, theoretical $12.26 \%$ ). As the analysis shows, at the next endo effect $\left(380^{\circ} \mathrm{C}\right)$ there is a complete oxidation of the remaining 0.9 mol of acetate ion and this is where the oxidation of methionine ion $(0.09 \mathrm{~mol})$ begins (mass loss: practical $26.0 \%$, theoretical $26.26 \%$ ). Oxidation of $0.43 \mathrm{~mol}$ of methionine ion (mass loss: practical $34.0 \%$, theoretical $34.07 \%$ ) corresponds to a strong exo effect at the temperature range of $480-650^{\circ} \mathrm{C}$. The strong exo process ends with the oxidation of the remaining $0.48 \mathrm{~mol}$ methionine ion at $630^{\circ} \mathrm{C}$, corresponding to a mass loss: practical $56.4 \%$, theoretical $57.62 \%$ ). The final product of thermolysis is a mixture of chromium oxide and sulfide $\mathrm{Cr}_{2} \mathrm{O}_{3}+\mathrm{Cr}_{2} \mathrm{~S}_{3}$. Which was confirmed by qualitative and quantitative analysis of thermolysis residue.

Compound $\mathrm{Cr}(\mathrm{Mt})_{2}\left(\mathrm{CH}_{3} \mathrm{COO}\right) \cdot 2 \mathrm{H}_{2} \mathrm{O}$ thermogram shows four endo and one strong exo effect. The first endo effect at $150^{\circ} \mathrm{C}$ corresponds to the dissolution of $2 \mathrm{H}_{2} \mathrm{O}$ mol of water (mass loss: practical 8.9\%, theoretical 9.26\%), the next endo effect $\left(240^{\circ} \mathrm{C}\right)$ is followed by $0.5 \mathrm{~mol}$ acetate ion (mass loss: practical $7.17 \%$, theoretical $7.24 \%$ ), third endoef $360^{\circ} \mathrm{C}$ ) 0.4 mol acetate ion oxidation (mass loss: practical $8.01 \%$, theoretical $7.75 \%$ ), the fourth endo-effect corresponds to the oxidation of $0.1 \mathrm{~mol}$ acetate ion and $1.0 \mathrm{~mol}$ methionine 
molecule (practical $76.89 \%$, theoretical $77.09 \%$ ), th Ends with strong exo effect $\left(540^{\circ} \mathrm{C}\right)$ (mass loss: practical $73.89 \%$, theoretical $74.16 \%$ ) with oxidation of $1.0 \mathrm{~mol}$ of methionine and formation of chromium sulfide. Which is a qualitative and quantitative analysis of the confirmed balance.

The $\mathrm{Cr}(\mathrm{Mt})_{3} \cdot 2 \mathrm{H}_{2} \mathrm{O}$ thermogram of the compound is characterized by several endo and one strong exoeffect, indicating that it is decomposing in stages. In particular, the first endo effect at $180^{\circ} \mathrm{C}$ corresponds to the dissolution of 2 mole of water (mass loss: practical $6.79 \%$, theoretical $6.82 \%$ ). At the second endo effect at $240^{\circ} \mathrm{C}$, methionine cleavage begins and the oxidation of $0.16 \mathrm{~mol} \mathrm{Mt}$ corresponds to a mass loss: practical $4.05 \%$, theoretical $4.86 \%$. The third endo effect at $350^{\circ} \mathrm{C}$ corresponds to an oxidation of $0.54 \mathrm{~mol} \mathrm{Mt}$ (mass loss: practical $16.87 \%$, theoretical $16.92 \%$ ). At the next endo effect at $410^{\circ} \mathrm{C}$ there is an oxidation of $1.27 \mathrm{~mol} \mathrm{Mt}$ (mass loss: practical $47.72 \%$, theoretical $47.91 \%$ ). A strong exo-effect at the temperature limit of $410-595^{\circ} \mathrm{C}$ corresponds to the complete oxidation of methionine, and the final product of thermolysis is a mixture of chromium sulfide and coal. The obtained result was confirmed by qualitative and quantitative analysis of the thermal balance.

To compare the thermal stability of methionine and chromium methionine, we weighed a certain mass of chromium methionine and a certain mass of pure methionine in a muffle oven at a temperature range of $150-500^{\circ} \mathrm{C}$. By calculating mass losses at a temperature interval of $500^{\circ} \mathrm{C}$. It was found that methionine practically completes decomposition at $200^{\circ} \mathrm{C}(80 \%)$, while chelate decomposition occurs gradually at the temperature range of $150-500^{\circ} \mathrm{C}$. Thus we can conclude that at the expense of the formation of chelate bonds in chelates not only increases the stability of chelates in aqueous solutions, but also increases the thermal stability.

Table 2

\begin{tabular}{|c|c|c|c|c|c|c|}
\hline \multicolumn{6}{|c|}{ Results of the rm ographic study of chrom ium chelate compounds } & \\
\hline \multirow{2}{*}{$\#$} & \multirow{2}{*}{ Formula } & \multirow{2}{*}{$\mathrm{T}^{0} \mathrm{C}$} & \multicolumn{2}{|c|}{ Mass loss, \% } & \multirow{2}{*}{\begin{tabular}{|c|} 
Torn \\
Molecule, \\
Molly \\
\end{tabular}} & \multirow{2}{*}{$\begin{array}{l}\text { A solid product of } \\
\text { decay }\end{array}$} \\
\hline & & & Pract. & Theoret. & & \\
\hline \multirow{5}{*}{1} & \multirow{5}{*}{$\mathrm{Cr}(\mathrm{M} \mathrm{t})\left(\mathrm{CH}_{3} \mathrm{COO}\right)_{2}$} & 230 & 8.9 & 9.26 & $0.5 \mathrm{CH}_{3} \mathrm{COO}^{-}$ & $\mathrm{Cr}(\mathrm{Mt})\left(\mathrm{CH}_{3} \mathrm{COO}\right)_{1.5}$ \\
\hline & & 270 & 12.4 & 12,26 & $0.6 \mathrm{CH}_{3} \mathrm{COO}^{-}$ & $\mathrm{Cr}(\mathrm{M} \mathrm{t})\left(\mathrm{CH}_{3} \mathrm{COO}\right)_{0.9}$ \\
\hline & & 380 & 26.0 & 26.26 & $0.9 \mathrm{CH}_{3} \mathrm{COO}^{-}+0.09(\mathrm{Mt})$ & $\mathrm{Cr}(\mathrm{M} \mathrm{t})_{0.91}$ \\
\hline & & 480 & 34.0 & 34.07 & $0.43(\mathrm{Mt})$ & $\operatorname{Cr}\left(\mathrm{Mt}_{0.48}\right.$ \\
\hline & & 630 & 30.4 & 30.52 & $0.48(\mathrm{Mt})$ & $\mathrm{Cr}_{2} \mathrm{O}_{3}+\mathrm{Cr}_{2} \mathrm{~S}_{3}$ \\
\hline \multirow{5}{*}{2} & \multirow{5}{*}{$\mathrm{Cr}(\mathrm{Mt})_{2}\left(\mathrm{CH}_{3} \mathrm{COO}\right) \cdot 2 \mathrm{H}_{2} \mathrm{O}$} & 150 & 8.95 & 8.12 & $2 \mathrm{H}_{2} \mathrm{O}$ & $\mathrm{Cr}(\mathrm{Mt})_{2}\left(\mathrm{CH}_{3} \mathrm{COO}\right)$ \\
\hline & & 240 & 7.17 & 7,24 & $0.5 \mathrm{CH}_{3} \mathrm{COO}^{-}$ & $\mathrm{Cr}(\mathrm{Mt})_{2}\left(\mathrm{CH}_{3} \mathrm{COO}\right)_{0.5}$ \\
\hline & & 360 & 8.01 & 7.75 & $0.4 \mathrm{CH}_{3} \mathrm{COO}^{-}$ & $\mathrm{Cr}(\mathrm{Mt})_{2}\left(\mathrm{CH}_{3} \mathrm{COO}\right)_{0.1}$ \\
\hline & & 410 & 76.89 & 77.09 & $0.1 \mathrm{CH}_{3} \mathrm{COO}^{-}+1.0(\mathrm{Mt})$ & $\operatorname{Cr}(\mathrm{M} t)$ \\
\hline & & 540 & 73.89 & 74.16 & $1.0(\mathrm{Mt})$ & $\mathrm{Cr}_{2} \mathrm{~S}_{3}$ \\
\hline \multirow{5}{*}{3} & \multirow{5}{*}{$\mathrm{Cr}(\mathrm{Mt})_{3} \cdot 2 \mathrm{H}_{2} \mathrm{O}$} & 180 & 6.79 & 6.82 & $2 \mathrm{H}_{2} \mathrm{O}$ & $\mathrm{Cr}(\mathrm{Mt})_{3}$ \\
\hline & & 240 & 4.86 & 4.85 & $0.16 \mathrm{Mt}$ & $\mathrm{Cr}(\mathrm{Mt})_{2,24}$ \\
\hline & & 350 & 16.87 & 16.92 & $0.54 \mathrm{Mf}$ & $\mathrm{Cr}\left(\mathrm{Mt}_{2,3}\right.$ \\
\hline & & 410 & 47.72 & 47.91 & $1.27 \mathrm{Mr}$ & $\operatorname{Cr}(\mathrm{Mt})_{1.03}$ \\
\hline & & 595 & 38.83 & 74.59 & $1.03 \mathrm{Mt}$ & $\mathrm{Cr}_{2} \mathrm{~S}_{3}+\mathrm{C}$ \\
\hline
\end{tabular}

Table 3. $\mathrm{Cr}(\mathrm{Mt})\left(\mathrm{CH}_{3} \mathrm{COO}\right)_{2}, \quad \mathrm{Cr}(\mathrm{Mt})_{2} \quad\left(\mathrm{CH}_{3} \mathrm{COO}\right) \cdot 2 \mathrm{H}_{2} \mathrm{O}$, $\mathrm{Cr}(\mathrm{Mt})_{3} \cdot 2 \mathrm{H}_{2} \mathrm{O}$ in synthetic chromium synthetic compounds were taken to determine the bonding character of methionine metal and the infrared absorption spectra of the compounds were studied.

The spectra are recorded $\left(500-5000 \mathrm{~cm}^{-1}\right)$ on a Speqtrometer Agilent Cary 630 FTIR spectrophotometer in the form of a suspension of fine dispersion powders in Vaseline oil (Table $3)$. It is known that methionine can play the role of a monodentant (with a $\mathrm{COO}^{-}$-group oxygen atom, or $\mathrm{NH}_{2}$ group nitrogen atoms) in compounds, as well as a bidentant ligand with the same oxygen and $\mathrm{NH}_{2}$ group nitrogen atoms. It was also found that amino acids, in accordance with the condition, form zwitter-ions $\left(\mathrm{NH}_{3}+-\mathrm{RCH}-\mathrm{COO}^{-}\right)$and bind with the metal with the oxygen of the carboxyl group and hydrogen $\mathrm{NH}_{3}+$ (hydrogen bond) $[16,17]$.

$\mathrm{Cr}(\mathrm{Mt})\left(\mathrm{CH}_{3} \mathrm{COO}\right)_{2}$ (I) of the study compounds; $\mathrm{Cr}(\mathrm{Mt})_{2}$ $\left(\mathrm{CH}_{3} \mathrm{COO}\right) \cdot 2 \mathrm{H}_{2} \mathrm{O}$ (II) and $\mathrm{Cr}(\mathrm{Mt})_{3} \cdot 2 \mathrm{H}_{2} \mathrm{O}$ (III) The assignment of some oscillation frequencies of the so-called absorption spectra is given in Table 3 .

Table 3.

\begin{tabular}{|c|c|c|c|l|}
\multicolumn{5}{|c|}{ IR Spectra of Absorption Vibration Bands of methionine-containing chromium chelates } \\
Compounds (cm-1). \\
\hline $\mathrm{Mt}$ & $\mathrm{Cr}(\mathrm{Mt})\left(\mathrm{CH}_{3} \mathrm{COO}\right)_{2}$ & $\mathrm{Cr}(\mathrm{Mt})_{2}\left(\mathrm{CH}_{3} \mathrm{COO}\right) \cdot 2 \mathrm{H}_{2} \mathrm{O}$ & $\mathrm{Cr}(\mathrm{Mt})_{3} \cdot 2 \mathrm{H}_{2} \mathrm{O}$ & Appropriation \\
\hline 3420 & 3395 & 3390 & 3394 & $v_{\text {as }}\left(\mathrm{NH}_{2}\right)$ \\
\hline 3320 & 3290 & 3250 & 3260 & $v_{\mathrm{s}}\left(\mathrm{NH}_{2}\right)$ \\
\hline 1635 & 1615 & 1645 & 1660 & $\delta\left(\mathrm{NH}_{2}\right)$ \\
\hline 1560 & 1550 & 1520 & 1580 & $v_{\text {as }}\left(\mathrm{COO}^{-}\right)$ \\
\hline 1420 & 1350 & 1345 & 1400 & $v_{\mathrm{s}}\left(\mathrm{COO}^{-}\right)$ \\
\hline- & 570 & 520 & 550 & $v(\mathrm{M}-\mathrm{N})$ \\
\hline- & 440 & 480 & 470 & $v(\mathrm{M}-\mathrm{O})$ \\
\hline & & & & \\
\hline
\end{tabular}

Table 3. The so-called absorption of compounds (1-3). In the range $3600-3000 \mathrm{~cm}^{-1}$ the wide absorption band can be attributed to the oscillations vas $\left(\mathrm{NH}_{2}\right)$ and vs $\left(\mathrm{NH}_{2}\right)$ of methionine. The complex nature of the absorption band is due to the overlap of the absorption bands of methionine and water molecules and the formation of hydrogen bonds between them. In the $1660-1615 \mathrm{~cm}^{-1}$ region, absorption bands belong to methionine $\delta\left(\mathrm{NH}_{2}\right)$. In the $1750-1720 \mathrm{~cm}^{-1}$ region $v(\mathrm{COOH})$ valence bands disappear completely and the asymmetric valence band vas $\left(\mathrm{COO}^{-}\right)$of the $\mathrm{COO}^{-}$ion occurs in the $1520-1580 \mathrm{~cm}^{-1}$ region and the $v \mathrm{~s}\left(\mathrm{COO}^{-}\right)$of the symmetric fluctuation band occurs in the $1400-1350 \mathrm{~cm}^{-1}$ in the area of which vas absorption band is most characteristic because it has a constant value [17]. In the $520-570 \mathrm{~cm}^{-1}$ and $440-480 \mathrm{~cm}^{-1}$ area, the absorption bands can be attributed to the valence fluctuations of the metal-nitrogen and metal-oxygen bonds. Therefore, it can be assumed that methionine acts as a cyclic ligand and binds to the metal to form five-membered metalcycles by means of amino group nitrogen and carboxyl ion $\left(\mathrm{COO}^{-}\right)$oxygen atoms, which is schematically represented as follows:

In order to determine the biological activity of methionine-containing chromium chelate compound, the effect of chelate on broiler productivity was studied. The experiment was conducted according to the following scheme: 


\begin{tabular}{|c|c|c|c|}
\hline \multicolumn{4}{|c|}{ Experiment scheme } \\
\hline Group & $\begin{array}{c}\text { Bird } \\
\text { number }\end{array}$ & $\begin{array}{c}\text { Growth } \\
\text { period }\end{array}$ & Chromium \\
\hline I control & 100 & 35 & - \\
II test & 100 & 35 & $50 \mathrm{mcg}$ \\
\hline III test & 100 & 35 & $100 \mathrm{mcg}$ \\
\hline IV test & 100 & 35 & $150 \mathrm{mcg}$ \\
\hline
\end{tabular}

In the first experiment, the effect of chromium chelate compound on broiler productivity was studied. The broiler live mass dynamics are given in Table 4.

Table 4

\begin{tabular}{|l|c|c|c|c|c|c|}
\hline \multicolumn{7}{|c|}{ Broiler live weight dynamic } \\
\hline \multirow{2}{*}{ Group } & \multicolumn{7}{|c|}{ Age, day } \\
\cline { 2 - 7 } & 1 & 7 & 14 & 21 & 28 & 36 \\
\hline I control & 41.28 & 179.00 & 460.15 & 866.20 & 1443.90 & 1962.73 \\
\hline II test & 40.80 & 182.57 & 481.90 & 901.10 & 1462.10 & 1971.00 \\
\hline III test & 40.95 & 178.70 & 466.96 & 896.91 & 1450.29 & 1975.30 \\
\hline IV test & 41.10 & 168.00 & 458.20 & 457.50 & 1413.70 & 1910.80 \\
\hline
\end{tabular}

Table 4The table shows that at the beginning of the experiment the live weight of the four groups of broilers is almost the same and amounts to 40.8-41.3 grams. In the first period of growth (up to 14 days) there is almost no difference in the live mass of the control and experimental group broilers, a slight difference is observed only in the second group. As for the middle period of growth (14-21 days), the positive effect of chromium chelate on the live mass is already observed here. On the 21st day the live weight of the II and III experimental group broilers is $4.5-5.1 \%$ higher than the control, and on the 28th day it is $2.6-3.4 \%$. (In both cases the difference is true for both steps $-\mathrm{R} \geq 0.01$ ). As for the first experimental group broilers, their live weight was only $2.0 \%$ higher than the control and the difference was not credible.

The broiler was slaughtered at 36 days of age. The live weight of the second and third group broilers at the time of slaughter was 1971-1975 grams, which was 60-65 g. (3.2-3.4\%) more than the live weight of the control group broiler (the difference is reliable in the first stage) for the first test In the group, the live weight of this group of broilers was $2.7 \%$ higher than that of the control group. As can be seen from the table, the broiler of the first group in all age groups is slightly behind the broiler of the second and third groups in terms of live weight. Thus, observations of live weight have shown that chromium chelate has a positive effect on live weight gain, which is noticeable from the second half of growth.

The calculation of absolute and daily weight gain showed that (Table 5) in the first period of growth (0-14 days), both absolute weight and daily weight gain in the experimental groups were $3-5 \%$ higher than the control, and compared to the middle period of growth (14-28 days). Absolute and daily weight gain is high in the second and third experimental groups. During the growing period (0-36 days) the highest was both absolute and daily weight gain in the second and third experimental groups (53.6-53.7).

Table 5
Abs olute and daily weight gain of broiler

\begin{tabular}{|l|c|c|c|c|c|c|}
\hline \multirow{2}{*}{ Groups } & \multicolumn{6}{|c|}{ Absolute growth } \\
\cline { 2 - 7 } & $0-7$ & $07--14$ & $14-21$ & $21-28$ & $28-36$ & $0-36$ \\
\hline \multirow{3}{*}{ control } & 138.50 & 281.00 & 406.00 & 577.70 & 518.80 & 1921.00 \\
\cline { 2 - 7 } & 19.80 & 40.10 & 58.00 & 79.60 & 77.00 & 53.40 \\
\hline \multirow{2}{*}{ II test } & 141.20 & 300.00 & 419.20 & 561.00 & 508.90 & 1930.00 \\
\cline { 2 - 7 } & 20.17 & 42.84 & 59.88 & 80.14 & 72.00 & 53.60 \\
\hline \multirow{2}{*}{ III test } & 138.00 & 288.00 & 430.00 & 553.00 & 525.00 & 1934.00 \\
\cline { 2 - 7 } & 19.71 & 41.10 & 61.10 & 79.00 & 75.00 & 53.70 \\
\hline \multirow{2}{*}{ IV test } & 127 & 290 & 399.30 & 556.20 & 497.10 & 1869.80 \\
\cline { 2 - 7 } & 18.14 & 41.42 & 57.04 & 79.45 & 71.01 & 51.93 \\
\hline
\end{tabular}

Table 5. The fall in these groups was 1 and 2 wings, the said birds fell in the first half of growth (up to 14 days), and the maintenance after 14 days was $100 \%$, which can not be said about the control group. The maintenance until the 21 st day was $98.8 \%$ ( 1 wing had fallen) and in the 21-36th day 3 wings fell, of which 2 wings with osti (infarction). As for the first test group here 2 wings fell with a trauma, which of course was considered a fall but the impact of any disease did not take place unlike the control.

Thus chromium significantly reduced the fallout caused by mastitis (infarction) in the experimental groups.

The highest maintenance during the growing period was in the second and third experimental groups - $97.14-98.0 \%$. (Table 6).

Table 6

\begin{tabular}{|l|l|c|c|c|c|c|}
\hline \multicolumn{7}{|c|}{ Broiler survival rate during the growing period } \\
\hline \multirow{3}{*}{ Group } & \multirow{2}{*}{ Indicator } & \multicolumn{5}{|c|}{ Age, day } \\
\cline { 3 - 7 } & & $0-7$ & $0-14$ & $0-21$ & $0-28$ & $0-36$ \\
\hline \multirow{4}{*}{ I control } & Initial number & 70 & 70 & 70 & 70 & 70 \\
\cline { 2 - 7 } & Final number & 69 & 68 & 66 & 66 & 66 \\
\cline { 2 - 7 } & survival & 98.60 & 97.14 & 94.28 & 94.28 & 94.28 \\
\hline \multirow{4}{*}{ III test } & Initial number & 70 & 70 & 70 & 70 & 70 \\
\cline { 2 - 7 } & Final number & 69 & 69 & 68 & 68 & 68 \\
\cline { 2 - 7 } & survival & 98.60 & 98.60 & 97.14 & 97.14 & 97.14 \\
\hline \multirow{3}{*}{ IV test } & Initial number & 70 & 70 & 70 & 70 & 70 \\
\cline { 2 - 7 } & Final number & 70 & 69 & 69 & 69 & 69 \\
\cline { 2 - 7 } & survival & 100.00 & 98.60 & 98.60 & 98.60 & 98.60 \\
\hline & Initial number & 70 & 70 & 70 & 70 & 70 \\
\cline { 2 - 7 } & Final number & 69 & 69 & 69 & 67 & 66 \\
\cline { 2 - 7 } & survival & 98.60 & 98.60 & 98.60 & 95.71 & 94.28 \\
\hline
\end{tabular}

Broiler survival rate during the growing period. Feed consumption was recorded by us during the growing period: The amount of consumed feed during the growing period, per wing is given in Table 7.

Table 7

\begin{tabular}{|c|c|c|c|c|c|}
\hline \multicolumn{7}{|c|}{ Cons umed feed in growing period } \\
\hline & \multicolumn{5}{|c|}{ Group } \\
\hline \multirow{2}{*}{ Day } & \multirow{2}{*}{ Unit } & I & II & III & IV \\
\cline { 3 - 6 } & & control & test & test & test \\
\hline $0-36$ & gr & 3480 & 3348 & 3528 & 3581 \\
\hline $0-36$ & $\%$ & 20.45 & 20.45 & 20.45 & 20.45 \\
\hline $0-36$ & kcal & 312 & 312 & 312 & 312 \\
\hline
\end{tabular}


Table 7 The table shows that the amount of feed consumed during the growing period in the experimental groups on 1 wing was 3348-3528 grams, while in the control group it was 3581 grams which is 233 and 53 grams more compared to the experimental. Accordingly, feed conversion was lowest in the experimental group and highest in the control group (Table 8 ). The feed conversion in the 2 nd experimental groups was $1.71 \mathrm{~kg}$. which was $0.11 \mathrm{~kg}$. or $6.0 \%$ less than in the control.

Table 8

\begin{tabular}{|l|c|c|c|c|c|}
\hline \multicolumn{7}{|c|}{ Geed conversion } \\
\hline \multirow{2}{*}{ Group } & \multicolumn{5}{|c|}{ Growing pe riod } \\
\cline { 2 - 6 } & $0-7$ & $0-14$ & $0-21$ & $0-28$ & $0-36$ \\
\hline I Control & 0.94 & 1.14 & 1.33 & 1.44 & 1.79 \\
\hline II test & 0.943 & 1.12 & 1.30 & 1.33 & 1.71 \\
\hline III test & 0.945 & 1.15 & 1.31 & 1.45 & 1.77 \\
\hline IV test & 0.949 & 1.18 & 1.39 & 1.51 & 1.82 \\
\hline
\end{tabular}

Table 9 consumption of nutrients (protein and energy) per wing was calculated.

As can be seen from the table, during the whole growing period (0-36 days) 1 and 3 group broilers consumed $720 \mathrm{~g}$. Protein, and the broiler of the second group - $709.6 \mathrm{~g}$. As for the control group broiler, they consumed $740.7 \mathrm{~g}$ during the whole growing period, which is $2.8-4.4 \%$ higher than in the experimental group. Similarly, in the control group, the energy consumption during the growth period is $2.2-2.9 \%$ higher.

Table 9

\begin{tabular}{|c|c|c|c|c|c|c|c|}
\hline \multicolumn{8}{|c|}{ Feed consumption per wing } \\
\hline \multirow{3}{*}{ Group } & $\begin{array}{c}\text { Protein/energy } \\
\text { Exchange }\end{array}$ & \multicolumn{7}{c|}{ Day } \\
\cline { 3 - 8 } & Protein & 37.80 & 79.12 & 136.74 & 190.85 & 276.0 & 720.51 \\
\hline \multirow{2}{*}{ I control } & Energy & 512.4 & 1122.4 & 1971.3 & 2969.6 & 4416.0 & 10992.0 \\
\cline { 2 - 8 } & Protein & 37.0 & 78.4 & 134.6 & 186.8 & 272.8 & 709.6 \\
\hline \multirow{2}{*}{ II test } & Energy & 510.3 & 1112.9 & 1951.3 & 2954.1 & 4400.0 & 10928.6 \\
\hline \multirow{2}{*}{ III test } & Protein & 38.0 & 79.55 & 136.53 & 190.85 & 275.4 & 720.3 \\
\cline { 2 - 8 } & Energy & 515.5 & 1128.5 & 1968.5 & 2979.2 & 4406.4 & 10998.1 \\
\hline \multirow{2}{*}{ IV test } & Protein & 38.3 & 80.84 & 140.83 & 196.8 & 284.0 & 740.72 \\
\cline { 2 - 8 } & Energy & 518.5 & 1146.8 & 2030.5 & 3000.7 & 4544.0 & 11246.0 \\
\hline
\end{tabular}

The efficiency of broiler meat production in broiler production is calculated by the European Index of Broiler Breeding Efficiency. This figure is given in the diagram (Fig 1).

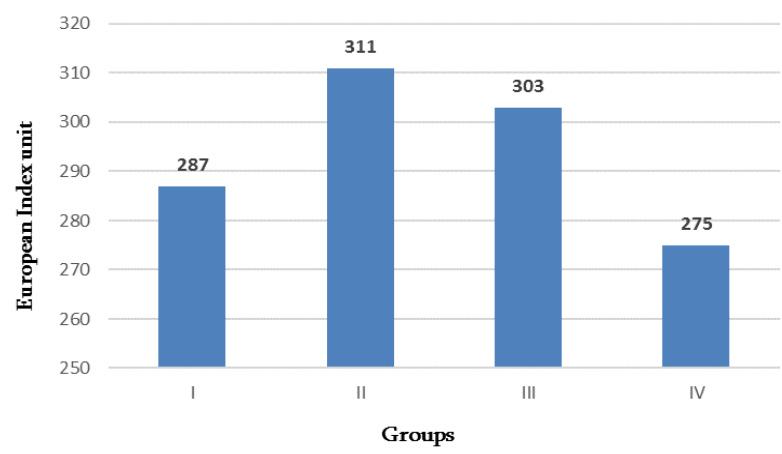

Fig.1

European Index of Broiler Breeding Efficiency

As can be seen from the diagram, broiler meat production is efficient (profitable) in all four groups, the European index of broiler breeding efficiency is highest in the second and third groups. 303-311 units, which is mainly explained by the use of the chelatic form of chrome.

\section{CONCLUSION}

Based on the research conducted, the following conclusions can be made:

$\checkmark$ Synthesis conditions established and methionine-containing chromium chelate compounds synthesized;

$\checkmark$ Chelates are individual compounds characterized by good solubility in water and dimethylformamide and poor solubility in alcohol and acetone;

$\checkmark$ According to the conductometric study of chelates, the formation of chelates occurs by about ten times a decrease in dissociation compared to the initial salt;

$\checkmark$ Thermal analysis has established that the thermal decomposition of compounds starts at the temperature range of $150-230^{\circ} \mathrm{C}$ and ends at the temperature range of $540-630^{\circ} \mathrm{C}$. Decomposition takes place in steps in the following order: 1-Water molecules are broken down; 2-oxidizing- acetate ions; 3-Oxidized methionine molecule. The final decomposition products are: (I) -a mixture of chromium sulfide and oxide; (II) A mixture of chromium sulfide and (III) a mixture of chromium sulfide and coal;

$\checkmark$ At the expense of the formation of chelate bonds increases the stability of chelates in aqueous solutions, as well as thermal stability in the solid state;

$\checkmark$ According to spectrophotometric research, methionine acts as a cyclic ligand and binds to chromium atoms by means of amino group nitrogen and carboxyl ion $\left(\mathrm{COO}^{-}\right)$oxygen atoms to form five-membered metalcycles;

$\checkmark$ The use of chromium in the broiler's growing form during broiler rearing has had a positive effect on broiler growth and development, as well as on maintenance, feed conversion, and nutrient uptake. Decreased broiler mortality by masters in the second half of adulthood (21-36 days);

$\checkmark$ The effective, optimal dose of chelated chromium is $100 \mathrm{mcg}$. Per $\mathrm{kg}$ of food.

\section{REFERENCES}

[1] G.Loginov Effect of metal chelates with amino acids and protein hydrolysates on the productive functions and metabolic processes in animal body. PhD, Kazan, Kazan Federal University, Russian Federation, 2005. (In Russian)

[2] N.Kochetkova Influence of metal citrates on biochemical indices of tissues and organs of chicken-broilers and the quality of the products "Specialty biochemistry " (2009). www.webpticeprom.ru. (In Russian)

[3] N.Kochetkova, A.Shaposhnikov, S.Zateev Citrates of biometals in the chicken-broiler's diet, J. Poultry Raising, (2010) www.webpticeprom.ru(In Russian)

[4] I.Boiko, I.Miroshnichenko Application of manganese citrate in rearing chicken-broilers." J. Poultry, Poultry Factory, 11, (2011), pp.10-17. (In Russian) 
[5] D.Pchelnikov, M.Titova, I.Tverskaya Others the role of trace elements and their chelate forms in the normalization of metabolism http://www.rusnauka.com/33 DWS 2010/33 DWS 2010/Veterenari a/74182.doc.htm(In Russian)

[6] J.Vincent Recent advances in the nutritional biochemistry of trivalent chromium. Proceedings of the Nutrition Society, 1, (2007), vol.63, p.41-47. (In USA)

[7] A.Kalashnikov, V.Fisinin, V.Shchuglov, N.Kleimanov, N.Pervov et al. Norms and rations in the feeding of agricultural animal 2003, Moscow, 456 p. (In Russian)

[8] S.Lebedev, S.Miroshnikov, O.N.Sukhanova, Sh.G. RakhmatullinMethod of elevation of productivity of broiler-chickens, Russian Federation, Patent for invention,\# 2370095 A23K 1/00. 2009. (In Russian)

[9] I.Draganov, M.Buryakova Working program of teaching discipline, Essentials of research in agricultural animals, Timiryazeva, 2006, p.13 (In Russian)

[10] I.Beshkenadze, S.Urotadze, N.Zhorzholiani, M.Gogaladze, N.Burkiashvili, L.Gogua Synthesis of the chelates containing amino acids and citric acid for creation of new generation premixes, Annals of Agrarian Science, 2, (2013) vol.11, pp.84-86. (In Georgian)

[11] I.Beshkenadze, S.Urotadze, N.Zhorzholiani, M.Gogaladze, G.Begheluri, N.Osipova, T.Kvernadze Chemical admix for poultry nutrition, Georgia, Sakpatenti, , \#U1800. 07.2014 (In Georgian)

[12] I.Beshkenadze, S.Urotadze, N.Zhorzholiani, M.Gogaladze, A.Chagelishvili, G.Begheluri Heteronuclear citrates containing admix for poultry feeding, Georgia, Sakpatenti, \# U1887. 31.2014, (In Georgian)

[13] I.Beshkenadze, S.Urotadze, A.Chagelishvili, N.Zhorzholiani, M.Gogaladze, G.Begheluri, N.Klarjeishvili New generation premixes of rabbit nutrition, Annals of Agrarian Science (2016) vol.14, pp.288-291.(http://dx.doi.org/10.1016/j.aasci.2016.06.001(In Georgian)

[14] I.Beshkenadze, A.Chagelishvili, M.Gogaladze, N.Klarjeishvili, G.Chagelishvili Study of physiological activity of microelements and glutamine acid-containing chelate citrates." Annals of Agrarian Science (2017) vol.15, pp.243-246. http://doi.org/10.1016/j.aasci.2017.12.002(In Georgian)

[15] I.Beshkenadze, G.Chagelishvili, M.Gogaladze Chelates in poultry feeding" LAP Lambert Academic Publishing (190790, ISBN 978-620-0-07888-9)

92p.https://www.lap-publishing.com/catalog/details/store/gb/book/97 8-620-0-07888-9/chelates-in-poultry-feeding?search=Chelates\%20in \%20poultry\%20feeding (In Germani)

[16] K.Nakamoto (1966)Infrakrasnye spektry neorganicheskich i koordinatsionnych soedinenii. 411(in Russian)

[17] L.Bellami (1963) Infrakrasnye cpektry slozhnykh molekul. M 590 (in Russian) 